\title{
Correlates of ultrasound diagnosed non alcoholic fatty liver disease in Indian adults with features of metabolic syndrome
}

\section{Imran Nazir Salroo ${ }^{1}$, Musharaf Bashir ${ }^{2}$, Rayees Ahmad Bhat ${ }^{2}$, Sheikh Imran Sayeed ${ }^{2}$}

${ }^{1}$ Radiodiagnosis Department, SKIMS Medical College, Bemina, Srinagar, Jammu and Kashmir, India

${ }^{2}$ Physiology Department, Government Medical College, Srinagar, Jammu and Kashmir, India

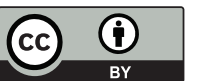

This work is licensed under a Creative Commons Attribution 4.0 International License

Received: 2020-01-21

Accepted: 2020-02-15

UDC: 618.1

\section{J Clin Med Kaz 2020; 1(55):17-21}

Corresponding Author: Musharaf Bashir, Demonstrator, Physiology Department, Government Medical College, Srinagar, Jammu and Kashmir, India. Tel.: +917042272380

E-mail: dr.musharaf.mb@gmail.com

\section{Abstract}

Because of its complex pathogenesis and scarcity of approved therapies, non-alcoholic fatty liver disease is considered as one of the major challenge before mankind. Literature suggests that non-alcoholic fatty liver disease will replace Hepatitis $\mathrm{C}$ as a major form of chronic liver disease in adults and children over the next decade thus becoming the major cause of liver transplantation.

Aim: To assess anthropometric, biochemical parameters and correlates of ultrasound-diagnosed non-alcoholic fatty liver disease patients.

Material and methods: For this study a total of 182 subjects were selected from the department of Radiodiagnosis and Imaging, SKIMS medical college, Bemina, Srinagar, Jammu and Kashmir, India. Control group consisted of 91 age and sex matched subjects (mean age $51.69 \pm 13.97$ years) whereas case group consisted of 91 subjects (mean age $50.72 \pm 12.13$ years). Ultrasound under standardized conditions was performed in all subjects and the grading of non-alcoholic fatty liver disease was done in case group. Correlation of anthropometric and biochemical parameters with the non-alcoholic fatty liver disease was sought from the case group.

Results: Non-alcoholic fatty liver disease patients had significantly higher body mass index [BMI $\left.\left(\mathrm{p}<0.0001^{* * *}\right)\right]$ and waist-to-hip ratio $\left(\mathrm{p}<0.003^{* *}\right)$, fasting glucose levels $\left(\mathrm{p}<0.0001^{* * *}\right)$ and triglycerides $(\mathrm{p}<0.0001 * * *)$. Furthermore, a positive correlation between the waist (inches) and non-alcoholic fatty liver disease was found.

Conclusion: Our findings further support that patients with signs of metabolic syndrome are at increased risk to develop non-alcoholic fatty liver disease. Furthermore abdominal obesity is an independent risk factor for nonalcoholic fatty liver disease.

Key words: non-alcoholic fatty liver disease (NAFLD), body mass index (BMI), abdominal obesity, waist, ultrasound

\footnotetext{
МЕТАБОЛИКАЛЫҚ СИНДРОМ БЕЛГІЛЕРІ БАР ЕРЕСЕК ҮНДІЛЕРДЕ УЛЬТРАДЫБЫС АРҚЫЛЫ ДИАГНОЗ ҚОЙЫЛҒАН АЛКОГОЛЬСІЗ МАЙЛЫ БАУЫР АУРУЫНЫҢ КОРРЕЛЯТТАРЫ (ӨЗАРА БАЙЛАНЫСТАРЫ) И.Н. Салру1 ${ }^{1}$ М. Башир ${ }^{2}$, Р.А. Бхат ${ }^{2}$ Ш.И. Саид²

${ }^{1}$ Сәулелік диагностика кафедрасы, Шер-и-Кашмир Медицина ғылымдары институтының медициналық колледжі,, Бемина, Сринагар, Джамму және Кашмир, Үндістан ${ }^{2}$ Физиалогия кафедрасы, Мемлекеттік медицина колледжі, Сринагар, Джамму және Кашмир, Үндістан
}

\section{ТҰЖЫРЫМДАМА}

Күрделі патогенезіне және емдеудің бекітілген әдістерінің болмауына байланысты алкогольсіз майлы бауыр ауруы адамзаттың басты проблемаларының бірі болып саналады. Әдебиеттер келесі онжылдықта алкогольсіз майлы бауыр ауруы С гепатитінің орнын алады, өйткені ересектер мен балаларда бауырдың созылмалы ауруының негізгі түрі болады, сондықтан бауыр трансплантациясының негізгі себебі болады деп болжайды.

Мақсаты: ультрадыбыс көмегімен диагноз қойылған алкогольсіз майлы бауыр ауруы бар науқастарда антропометриялық, биохимиялық көрсеткіштер мен корреляттарды бағалау.

Материалдар мен әдістер: Осы зерттеуді жүргізу үшін Медициналық ғылымдар институтының Шери-Кашмир, Бемина, Сринагар Джамму және Кашмир, Үндістан, Медициналық колледждің сәулелік диагностика және кескіндеме кафедрасының барлығы 182 субъектісі іріктелді. Бақылау тобына жасы мен жынысы бойынша таңдалған 91 субъект кірді (орташа жасы 51,69 \pm 13.97 жас), қадағалау тобына 91 субъект кірді (орташа жасы 50,72 12.13 жас). Барлық субъектілерге ультрадыбыстық зерттеу жүргізілді, алкогольсіз майлы бауыр ауруы бақылау тобында бағаланды. 
Нәтижелер: алкогольсіз майлы бауыр ауруы бар науқастарда дене салмағының индексі айтарлықтай жоғарылаған [ИМт (р <0.0001 $\left.\left.{ }^{* * *}\right)\right]$ және бел-жамбас индексі $\left(\right.$ p <0.003 **), аш қарынға қандағы глюкоза деңгейі $\left.(p<0.0001){ }^{* * *}\right)$ және триглицеридтер $(p<0.0001$ ***). Сонымен қатар, бел (дюйм) және алкогольсіз майлы бауыр аурулары арасында оң корреляция анықталды.

Қорытынды: Біздің нәтижелеріміз метаболикалық синдром белгілері бар пациенттердің алкогольсіз майлы бауыр ауруының даму қаупінің жоғарылайтынын растайды. Сонымен қатар, іштің семіздігі алкогольсіз майлы бауыр ауруының дамуының тәуелсіз факторы болып табылады.

Негізгі сөздер: алкогольсіз бауыр ауруы, дене салмағының индексі, іш семіздігі, бел, ультрадыбыс

\section{КОРРЕЛЯТЫ НЕАЛКОГОЛЬНОЙ ЖИРОВОЙ БОЛЕЗНИ ПЕЧЕНИ, ДИАГНОСТИРОВАННОЙ УЛЬТРАЗВУКОМ У ВЗРОСЛЫХ ИНДУСОВ С ПРИЗНАКАМИ МЕТАБОЛИЧЕСКОГО СИНДРОМА}

И.Н. Салру1, М. Башир 2 , Р.А. Бхат ${ }^{2}$, Ш.И. Саид ${ }^{2}$

${ }^{1}$ Кафедра лучевой диагностики, Медицинский колледж института медицинских наук Шер-и-Кашмир, Бемина, Сринагар, Джамму и Кашмир, Индия

${ }^{2}$ Кафедра физиологии, Государственный медицинский колледж, Сринагар, Джамму и Кашмир, Индия

\section{PE3ЮME}

В силу своего сложного патогенеза и дефицита одобренных методов лечения, неалкогольная жировая болезнь печени считается одной из основных проблем, стоящих перед человечеством. Литература предполагает, что в ближайшее десятилетие неалкогольная жировая болезнь печени займет место гепатита С, как основной фрормы хронического заболевания печени у взрослых и детей, и таким образом станет основной причиной трансплантации печени.

Цель: Оценить антропометрические, биохимические параметры и корреляты у пациентов с неалкогольной жировой болезнью печени, диагностированной с помощью ультразвука.

Материал и методы: Для настоящего исследования было отобрано всего 182 субъекта кафедры лучевой диагностики и визуализации, Медицинский колледж института медицинских наук Шер-и-Кашмир, Бемина, Сринагар, Джамму и Кашмир, Индия. Контрольная группа состояла из 91 субъекта, подобранных по возрасту и полу (средний возраст составил $51.69 \pm 13.97$ лет), группа наблюдения также включала 91 субъект (средний возраст составил $50.72 \pm 12.13$ лет). Для всех субъектов проведено ультразвуковое исследование при стандартных условиях и в группе наблюдения была проведена оценка неалкогольной жировой болезни печени. Проведена корреляция антропометрических и биохимических показателей неалкогольной жировой болезни печени в группе наблюдения.

Результаты: У пациентов с неалкогольной жировой болезнью печени был значительно более высокий индекс массы тела [ИМТ $\left.\left(p<0.0001^{* * *}\right)\right]$ и индекс талия-бедро $\left(p<0.003^{* *}\right)$, уровни содержания глюкозы в крови натощак $\left(p<0.0001^{* * *}\right)$ и триглицеридов $\left(p<0.0001^{* * *}\right)$. Кроме того, была обнаружена положительная корреляция между талией (дюймы) и неалкогольной жировой болезнью печени.

Заключение: Наши результаты также подтверждают, что у пациентов с признаками метаболического синдрома повышен риск развития неалкогольной жировой болезни печени. Кроме того, абдоминальное ожирение является независимым фактором риска развития неалкогольной жировой болезни печени.

Ключевые слова: неалкогольная жировая болезнь печени, индекс массы тела, абдоминальное ожирение, талия, ультразвук

\section{Introduction}

Non alcoholic fatty liver disease (NAFLD) is an umbrella term that covers a range of liver diseases from steatosis, nonalcoholic steatohepatitis (NASH) and liver cirrhosis [1]. According to the American Association of Liver Diseases, NAFLD is defined as an accumulation of fat in the liver exceeding $5 \%$ to $10 \%$ by weight [1]. NAFLD is the commonest cause of liver disease in Western countries. Literature suggests that NAFLD affects $25 \%$ of the population globally with a range of $13.5 \%$ in Africans and $31.8 \%$ in the Middle-East [2]. It has been seen that obesity and Type 2 diabetes mellitus are strongly linked with NAFLD. Moreover NAFLD has a prevalence of approximately $70 \%$ in obese people who have Type 2 diabetes mellitus (DM) [3]. With the increasing prevalence of obesity and metabolic syndrome, non-alcoholic fatty liver disease (NAFLD) would be the leading indication for liver transplant $[4,5,6]$. Studies have shown that subjects who have abdominal obesity and other features of metabolic syndrome such as hyperglycemia, hypertriglyceridemia and hypertension are at a heightened risk of having NAFLD as well as cardiovascular disease $[7,8]$. NAFLD is surfacing as a significant cause of liver disease in India. Literature suggests that prevalence of NAFLD in around $9 \%$ to $32 \%$ of general population in India with higher prevalence in those with obesity, diabetes or prediabetes. Nearly half of Indian patients with NAFLD have evidence of full-blown metabolic syndrome [9].

NAFLD has been seen to occur at all ages including childhood though its prevalence increases with age [10,11]. Changes associated with urbanization such as sedentary life style, fat rich diet, and a higher inherited tendency for diabetes mellitus makes Indians more prone to NAFLD [12]. It has been observed that Type $2 \mathrm{DM}$ is a major risk factor for presence and severity of NAFLD [13]. Most patients with NAFLD are initially asymptomatic and are diagnosed due to an incidental detection of fatty liver on ultrasonography [9].

Ultrasound is a non-invasive and readily available tool that has a significant role in diagnosing NAFLD [14]. On ultrasound, bright hepatic echoes, increased hepatorenal echogenicity and vascular blurring of portal or hepatic vein have been classified as unique sonographic features of NAFLD [14].

The aim of this study was sonographic evaluation of those subjects, for possible NAFLD, who had features of metabolic syndrome and to see the correlation of NAFLD with abdominal obesity.

\section{Material and methods}

This observational study was conducted in the Department of Radioganosis and Imaging, SKIMS, Bemina, Srinagar, J\&K, India in collaboration with the Department of Physiology, Government Medical College, Srinagar, J\&K, India. This study was begun after obtaining clearance from the Institutional Ethical Committee. A total of 180 subjects consisting of 90 ultrasound diagnosed NAFLD, adults aged (50.72 \pm 12.13$)$ and 90 healthy adult controls aged $(51.69 \pm 13.97)$ were worked up for this study from the Department of Radiodiagnosis, SKIMS, Bemina. Anthropometric measurements and biochemical tests were done in the Outpatient Department of SKIMS Medical College, Bemina.

\section{Exclusion criteria:}

Subjects having history of any chronic liver disease, history of alcohol consumption, malignancies, those receiving any form of chemotherapy were excluded from this study. Subjects on medications known to cause hepatic steatosis (such as estrogens, corticosteroids, amiodarone and valproate).

Data was sent to the Department of Physiology, Government Medical College, Srinagar for further evaluation and analysis. 


\section{Procedure}

Anthropometric measurements such as body mass index (BMI), waist (in inches), hips (in inches) and waist/hip ratio was sought from all the subjects. Biochemical tests such as fasting blood sugar, serum triglycerides levels were done in all participants. Those subjects who had elevated fasting blood sugar and triglycerides were subjected to further evaluation by high end ultrasound [(Siemen Acusson,x-300), Siemens, Erlangen, Germany] using a 3-5 MHz transducer for detection of possible NAFLD. Healthy controls who had normal levels of triglycerides and fasting blood sugar were also evaluated by ultrasound to compare the sonographic features. All the participants were made to lie supine and ultrasound evaluation for NAFLD was done. In patients with sonographic features of NAFLD such as increased hepatic echogenicity, poor echo penetration into the deep portion of the liver and poor visualization of hepatic blood vessel structures in the liver were looked for. Liver was said to be normal if there was homogenous texture and was minimally hyperechoic or isoechoic when compared with the normal renal cortex.

Severity of NAFLD was graded using five-point scale, as follows: normal (grade 0), mild (grade 1), moderate (grade 2) and severe (grade 3) [15].
The data was further evaluated and analyzed in the Department of Physiology, Government Medical College, Srinagar by statistical software Graph-pad version 6, Graphpad software inc, California, USA. Normality test was done using D’Agostino Pearson test. Data was compared using Paired T-test. $\mathrm{P}$ value $<0.05$ was considered to be significant. Pearson's rank coefficient of correlation/ Spearman's coefficient of correlation was used wherever necessary. $\mathrm{P}$ value of $<0.05$ was taken as significant.

\section{Results}

Data obtained from all the 180 participants was analyzed. Case group consisted of adults aged $(50.72 \pm 12.13)$ years whereas the control group comprised of adults aged $(51.69 \pm$ 13.97) years. Anthropometric measurements (such as age, BMI, waist/hip ratio) and biochemical parameters (i.e. fasting blood glucose, triglycerides) of both the groups were compared as shown in Table 1. There was no statistically significant difference in age between the two groups. Data was expressed in terms of mean \pm SD. It was observed that the BMI of the case group $\left(29.62 \pm 5.09 \mathrm{~kg} / \mathrm{m}^{2}\right)$ as compared to the control group (23.06 $\left.\pm 2.27 \mathrm{~kg} / \mathrm{m}^{2}\right)$ was very significantly higher $\left(\mathrm{p}<0.0001^{* * *}\right)$ as shown in Table 1.

Table 1 Comparison of various anthropometric and biochemical parameters between control and case group

\begin{tabular}{|l|l|l|l|}
\hline Parameters & Control group (N=90) & Case group & P value \\
\hline & & $(\mathrm{N}=90)$ & \\
\hline Age (years) & $51.69 \pm 13.97$ & $50.72 \pm 12.13$ & 0.81 \\
\hline BMI $\left(\mathrm{Kg} / \mathrm{m}^{2}\right)$ & $23.06 \pm 2.27$ & $29.62 \pm 5.09$ & $<0.0001^{* * *}$ \\
\hline Waist/ hip ratio & $0.94 \pm 0.04$ & $0.99 \pm 0.12$ & $0.003^{* *}$ \\
\hline Fasting blood sugar (gm/dl) & $87.31 \pm 5.90$ & $104.1 \pm 29.80$ & $<0.0001^{* * *}$ \\
\hline Triglycerides mg/dl & $148.6 \pm 14.91$ & $189.5 \pm 37.90$ & $<0.0001^{* * *}$ \\
\hline
\end{tabular}

$\mathrm{N}$ : number of subjects; BMI: Body mass index; **Highly significant; ***Very highly significant.

Data is expressed as mean $\pm \mathrm{SD}$.

Waist/hip ratio of the case group $(0.99 \pm 0.12)$ as compared to the control group $(0.94 \pm 0.04)$ was significantly higher $(\mathrm{p}<0.003 * *)$ as shown in Table 1 . Biochemical parameters such as fasting blood glucose in case group $(104.1 \pm 29.80 \mathrm{gm} / \mathrm{dl})$ as compared to the control group $(87.31 \pm 5.90 \mathrm{gm} / \mathrm{dl})$ was very significantly high $\left(\mathrm{p}<0.0001^{* * *}\right)$ as shown in Table 1 . Finally triglycerides in case group $(189.5 \pm 37.90)$ as compared to the control group $(148.6 \pm 14.91)$ was very significantly high $\left(p<0.0001^{* * *}\right)$. It was also observed that the grade of NAFLD was positively correlated with waist (in inches) as shown in Figure 1.

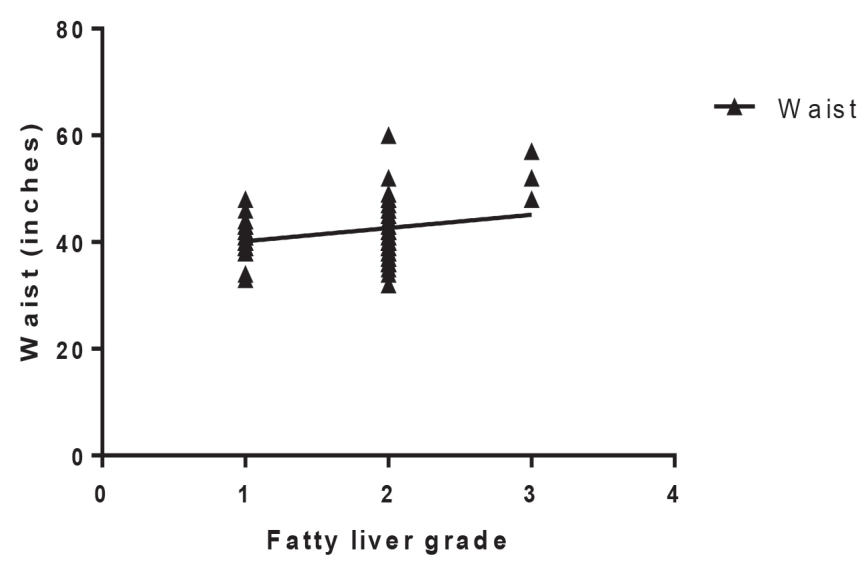

Figure 1

Journal of Clinical Medicine of Kazakhstan: Volume 1, Number 55, Issue 2020

\section{Discussion}

Ultrasound is a widely available, easy to perform and less expensive technique for initial screening and evaluation in subjects suspected of having NAFLD [15]. In this study it was observed that BMI of case group was significantly higher than the controls $\left(\mathrm{p}<0.0001^{* * *}\right)$. Singh SP et al [16] in a study from the coastal regions of India found that $39(24.5 \%)$ of 159 healthy attendants of patients had evidence of fatty liver on ultrasound (males 27\%, females 14\%). Subjects who had fatty liver changes on ultrasound had a higher BMI (mean $25.9 \pm 4.2 \mathrm{~kg} / \mathrm{m}^{2}$ ) than those without changes (mean $22.1 \pm 3.3 \mathrm{~kg} / \mathrm{m}^{2}$ ). In another study, Das $\mathrm{K}$ et al [17] found that the risk of NAFLD was highest in those with BMI $>25 \mathrm{~kg} / \mathrm{m}^{2}$. In our study we also observed that subjects who had features of NAFLD on ultrasound had very significantly higher BMI $(29.62 \pm 5.09)$ than controls.

Central / abdominal obesity is highly prevalent in SouthEast Asian region including India even when the BMI $<25 \mathrm{~kg} / \mathrm{m}^{2}$ [18]. Kim et al [19] in a study found that the waist circumference was increased in those who had features of NAFLD. In another study, Mona A et al [20] showed that fatty liver detected by ultrasound was significantly higher in those who had higher waist/hip ratio $(\mathrm{P}=0.001)$. We also observed in our study that waist/hip ratio of ultrasound diagnosed NAFLD subjects was highly significant $(p=0.003 * *)$ than controls.

At present NAFLD is regarded as one of the essential part of metabolic syndrome which is characterized by increased waist circumference, increased fasting glucose, increased triglycerides 
and hypertension. As defined by the adult treatment panel III (ATP III) metabolic syndrome is defined by presence of at least 3 of the 5 criteria which includes obesity, hyperglycemia, increased BMI, hypertriglyceridemia and hypertension [9]. A study by Mona A et al [20], in which there were 18 participants, showed that the fasting glucose levels in ultrasound diagnosed NAFLD subjects was significantly higher $(p<0.05)$ as compared to healthy controls. In a study by Duseja A et al they found that 35 out of $40(88 \%)$ nonalcoholic patients with increased fasting glucose had evidence NAFLD on ultrasound [13]. Our findings are similar to the above mentioned studies. We observed that the fasting blood glucose of subjects with sonographic features of NAFLD was very significantly high $(\mathrm{p}<0.0001 * * *)$.

It is a well known fact that Insulin inhibits the production of very low density lipoproteins (VLDL) from the liver. In fatty liver disease, this action of insulin is compromised whereas VLDL clearance remains unchanged. The overproduction of VLDL results in increased triglycerides [21]. In a study by Nayak $\mathrm{NC}$ ert al [22] high triglycerides were observed, being present in $53 \%$ patients with NAFLD. Mona A et al [20], in a study which included 55 participants out of which 39 had features of NAFLD, observed significantly increased level of triglycerides $(p=0.003)$ in subjects diagnosed with NAFLD. Gupte P et al [23] in a study from Mumbai showed that 49 of 100 patients with increased fasting blood sugar had evidence of fatty liver on ultrasound. They further observed increased triglycerides in subjects diagnosed with NAFLD.
There is plenty of literature to suggest that Asians have more intra-abdominal adipose tissue than white Caucasians [9]. A study by Kirvoski $G$ et al [24] demonstrated that the waist circumference was strongly correlated with NAFLD. In another study by Duseja A et al [9], in which 1168 subjects participated, found that there was a strong correlation of waist circumference with NAFLD. We observed that the waist circumference had statistically significant positive correlation with the grade of NAFLD which means that the possibility of NAFLD increases with the increase in abdominal obesity.

\section{Conclusion}

In this study we observed that subjects who had higher BMI, central/abdominal obesity, hyperglycemia and hypertriglceridemia, which are essential components of metabolic syndrome, had sonographic features of NAFLD. Furthermore severity of NAFLD increased with the increase in central obesity i.e. waist circumference. Thus we conclude that the routine sonographic evaluation of patients with features of metabolic syndrome is of paramount significance which may help in early detection of NAFLD and increase quality of life in these patients.

\section{Lacunae}

Major limitation of this study is a small sample size and the intra and inter-observer variability of ultrasound.

Disclosures: There is no conflict of interest for all authors.

\section{References}

1. Johannes W, Rau M, Andreas G. Non-alcoholic fatty liver disease: Epidemiology, Clinical course, Investigation and Treatment. Dtsch Arztebl Int. 2014; 111(26):447-52.

2. Younossi ZM, Giulio M, Helena PC, Salvatore P. Epidemiology of Nonalcoholic fatty liver disease and nonalcoholic steatohepatitis: Implications for liver transplantation. Transplantation. 2019; 103(1):22-7. https://doi.org/10.1097/TP.0000000000002484

3. Dharmalingham M, Yamasandhi PG. Non alcoholic fatty liver disease and Type 2 diabetes mellitus. Indian J Endocrinol Metab. 2018; 22(3):421-28. https://doi.org/10.4103/ijem.IJEM_585_17

4. Rinella ME. Nonalcoholic fatty liver disease: a systematic review. JAMA. 2015; 313:2263-73. https://doi.org/10.1001/ jama.2015.5370

5. Brunt EM et al. Nonalcoholic fatty liver disease. Nat Rev Dis Primers. 2015; 15080. https://doi.org/10.1038/nrdp.2015.80

6. Wong RJ et al. Nonalcoholic steatohepatitis is the second leading etiology of liver disease among adults awaiting liver transplantation in the United States. Gastroenterology. 2015; 148:547-55. https://doi.org/10.1053/j.gastro.2014.11.039

7. Yang S, Kwak S, Lee JH, Kang S, Lee SP. Non alcoholic fatty liver disease is an early predictor of metabolic diseases in a metabolically healthy population. PLOS ONE. 2019; 14(11). https://doi.org/10.1371/journal.pone.0224626

8. Rodriguez SM, Margareth D, Filho M, Moraes JE. Metabolic syndrome and risk factors for non alcoholic fatty liver disease. Arq Gastroenterol. 2012; 49(1):89-96. https://doi.org/10.1590/S0004-28032012000100015

9. Duseja A. Nonalcoholic fatty liver disease in India - a lot done, yet more required! Indian J Gastroenterol 2010; (29):217-25. https://doi.org/10.1007/s12664-010-0069-1

10. AGA technical review on nonalcoholic fatty liver disease. Gastroenterology. 2002; 123:1705-25. https://doi.org/10.1053/ gast.2002.36572

11. Benedict M, Zhano X. Non alcoholic fatty liver disease: An expanded review. World J Hepatol. 2017; 9(16):715-32. https://doi. org/10.4254/wjh.v9.i16.715

12. Singh SP, Nayak S, Swain M, et al. Prevalence of nonalcoholic fatty liver disease in coastal eastern India: a preliminary ultrasonographic survey. Indian J Gastroenterol. 2004; 25:76-9.

13. Duseja A, Bhansali A, Bhadada S, Jain P, Dhiman RK, Chawla Y. Nonalcoholic fatty liver disease in patients with recent onset type 2 diabetes mellitus (abstract). J Gastroenterol Hepatol. 2004; 19:A402.

14. Khov N, Sharma A, Riley TR. Bedside ultrasound in the diagnosis of nonalcoholic fatty liver disease. World J Gastroenterol. 2014; 20(22):6821-25. https://doi.org/10.3748/wjg.v20.i22.6821

15. Lee SS, Park SH, Kim HJ, Kim SY, Kim MY, Kim DY, Suh DJ, Kim KM, Bae MH, Lee JY, Lee SG, Yu ES. Non-invasive assessment of hepatic steatosis: prospective comparison of the accuracy of imaging examinations. J Hepatol. 2010; 52:579-585. https://doi.org/10.1016/j.jhep.2010.01.008

16. Singh SP, Nayak S, Swain M, et al. Prevalence of nonalcoholic fatty liver disease in coastal eastern India: a preliminary ultrasonographic survey. Indian J Gastroenterol. 2004; 25:76-9. 
17. Das K, Mukherjee PS, et al. Nonobese population in a developing country has a high prevalence of nonalcoholic fatty liver and significant liver disease. Hepatology. 2010; 51:1593-602. https://doi.org/10.1002/hep.23567

18. Misra A, Vikram NK. Clinical and pathophysiological consequences of abdominal adiposity and abdominal adipose tissue depots. Nutrition. 2003; 19:457-66. https://doi.org/10.1016/S0899-9007(02)01003-1

19. Kim HC, Choi SH, Shin HW, Cheong JY, Lee KW, Lee HC et al. Severity of ultrasonographic liver steatosis and metabolic syndrome in Korean men and women. World J Gastroenterol. 2005; 11:5314-21. https://doi.org/10.3748/wjg.v11.i34.5314

20. Mona AH et al. Liver ultrasound is more sensitive in assessing the severity of nonalcoholic fatty liver disease with homeostasis model assessment-insulin resistance. Egyptian Liver Journal. 2012; 2:41-6. https://doi.org/10.1097/01.ELX.0000412375.06564. cd

21. Mittendorfer B, Yoshino M, Patterson BW, Klein S. VLDL Triglyceride kinetics in lean, overweight and obese men and women. J Clin Endocrinol Metab. 2016; 101(11):4151-60. https://doi.org/10.1210/jc.2016-1500

22. Nayak NC, Vasdev N, Saigal S, Soin AS. End-stage nonalcoholic fatty liver disease: evaluation of pathomorphologic features and relationship to cryptogenic cirrhosis from study of explant livers in a living donor liver transplant program. Hum Pathol. 2010; 41:425-30. https://doi.org/10.1016/j.humpath.2009.06.021

23. Gupte P, Amarapurkar D, Agal S, et al. Non alcoholic steatohepatitis in type 2 diabetes mellitus. J Gastroenterol Hepatol. 2004; 19:854-8. https://doi.org/10.1111/j.1440-1746.2004.03312.x

24. Kirvoski $\mathrm{G}$ et al. Prevalence of ultrasound-diagnosed non-alcoholic fatty liver disease in a hospital cohort and its association with anthropometric, biochemical and sonographic characteristics. Int J Clin Exp Med. 2010; 3(3): 202-10. https://doi. org/10.1055/s-0029-1246560

How to cite this article: Imran Nazir Salroo, Musharaf Bashir, Rayees Ahmad Bhat, Sheikh Imran Sayeed. Correlates of ultrasound diagnosed non alcoholic fatty liver disease in Indian adults with features of metabolic syndrome. J Clin Med Kaz. 2020; 1(55):17-21 